Suminar, E. • I. R. D. Anjarsari · A. Nuraini · Hapizhah

\title{
Pertumbuhan dan perkembangan tunas nilam var. Lhoukseumawe dari jenis eksplan dengan sitokinin yang berbeda secara in vitro
}

\section{Shoot growth and development of patchouli plant var. Lhoukseumawe in different of explant types and cytokinin through in vitro}

Diterima : 15 September 2015/Disetujui : 15 Oktober 2015 / Dipublikasikan : Oktober 2015

CDepartment of Crop Science, Padjadjaran University

\begin{abstract}
The aim of this research was to find out the method of patchouli miropropagation through using different explant types and cytokinin concentration in vitro. The experiment was carried out at Seed Technology Tissue Culture Laboratory, Faculty of Agriculture, University of Padjadjaran from March until June 2012. A factorial Randomized Complete Design was used in this experiment, consisted of two factors and three replications. The first factor was explant type: single node, shoot apex, and leaf. The second factor was type and concentration of cytokinin: $0 \mathrm{mg} \mathrm{L}^{-1}, 0,5 \mathrm{mgL}^{-1} \mathrm{BAP}, 1,0 \mathrm{mgL}^{-1}$ $\mathrm{BAP} 0,5 \mathrm{mgL}^{-1}$ zeatin, and $1,0 \mathrm{mgL}^{-1}$ zeatin. The result of the experiment showed that apex explant with $0,5 \mathrm{mgL}^{-1} \mathrm{BAP}$ has the best number of shoots, height of shoot, fresh weight, and number of leaves at 12 wai (week after inoculation).
\end{abstract}

Keywords: BAP · Explant · Patchouli · In vitro · Zeatin

Sari Tujuan dari penelitian ini adalah untuk mendapatan metode perbanyakan tanaman nilam melalui teknik in vitro dengan menggunakan jenis eksplan serta jenis dan konsentrasi sitokinin yang berbeda. Percobaan dilaksanakan di Laboratorium Teknologi Benih Fakultas Pertanian Universitas Padjadjaran dari bulan Maret sampai dengan Juni 2012. Rancangan percobaan menggunakan Rancangan Acak Lengkap pola faktorial yang terdiri dua faktor dan tiga kali ulangan. Faktor pertama

\footnotetext{
Dikomunikasikan oleh Y. Maxiselly

Suminar, E ${ }^{1}$. · I.R.D. Anjarsari ${ }^{1}$. A. Nuraini ${ }^{1}$. Hapizhah ${ }^{2}$

1 Dept. Budadaya Pertanian Fakultas Pertanian Unpad

2 Alumni Program Sarjana Agroteknologi Unpad

Korespondensi: suminarerni@yahoo.com
}

adalah tipe eksplan (mata tunas, pucuk, dan daun). Faktor kedua adalah tipe dan konsentrasi sitokinin $\left(0 \mathrm{mg} \mathrm{L}^{-1}, 0,5 \mathrm{mgL}^{-1} \mathrm{BAP}, 1,0 \mathrm{mgL}^{-1}\right.$ BAP0,5 mgL-1 zeatin, and 1,0 mgL-1 zeatin). Hasil percobaan menunjukkan bahwa eksplan pucuk dengan penggunaan $0.5 \mathrm{mg} \mathrm{L}^{-1}$ menghasilkan jumlah tunas, tinggi tunas, bobot segar dan jumlah daun tertinggi pada $12 \mathrm{msi}$ (minggu setelah inokulasi).

Kata kunci: BAP · Eksplan · Nilam · In vitro . Zeatin

\section{Pendahuluan}

Tanaman nilam (Pogostemon cablin Benth) merupakan salah satu tanaman penghasil minyak atsiri yang dapat dipergunakan untuk kepentingan farmasi terutama untuk industri parfum dan aroma terapi. Hingga saat ini, di pasar internasional Indonesia merupakan pemasok minyak nilam terbesar berkisar $85 \%$ dengan rata-rata volume ekspor $1.057 \mathrm{t} /$ tahun (Wahyudi dan Ermiati, 2012). Berdasarkan informasi dari Asosiasi Minyak Atsiri Indonesia yang menyebutkan bahwa produksi minyak nilam Indonesia tahun 2011 menurun dibandingkan tahun 2010 dimana pada tahun 2011 produksi minyak nilam sebanyak 800 ton, sedangkan tahun 2010 mampu memproduksi hingga 1.000 ton (Rahmat 2011), selain itu rendahnya kualitas minyak nilam salah satunya disebabkan oleh kemungkinan bibit yang ditanam bukan varietas unggul, sehingga rendemen minyak nilam yang dihasilkan relatif rendah (Yuhono dan Suhirman 2006).

Salah satu upaya peningkatan kualitas minyak ini diantaranya dapat dilakukan dengan penggunaan bibit unggul yang memiliki kualitas 
minyak yang diinginkan, namun ketersediaan jumlah bibit unggul yang tersedia masih terbatas. Badan Penelitian dan Pengembangan Departemen Pertanian hanya mampu menyediakan benih sebar dari kultivar Sidikalang, Tapak Tuan dan Lhokseumawe sebanyak 22.000 setek dalam satu kali produksi dengan tenggang waktu penyediaan selama 5 bulan, dibandingkan dengan kebutuhan bibit yang diperlukan petani yaitu sebanyak 451.840 .000 setek/tahun benih tersebut sangat kurang mencukupi (Direktorat Jenderal Perkebunan, 2007).

Metode alternatif untuk perbanyakan bibit unggul dalam waktu yang relatif singkat dapat dilakukan melalui kultur jaringan. Salah satu usaha yang dilakukan untuk perbanyakan bibit nilam adalah dengan teknik kultur jaringan. Keuntungan penyediaan benih melalui kultur jaringan diantaranya dapat mengeliminir penyakit (bebas dari mikroba/virus) dalam jumlah besar dan seragam (Hadipoentyanti, 2010). Keberhasilan dalam perbanyakan secara in vitro ditentukan oleh banyak faktor diantaranya jenis eksplan dan zat pengatur tumbuh (Swamy et al. 2010; Hua et al. 2014; Norrizah et al. 2012).

\section{Bahan dan Metode}

Penelitian dilakukan di Laboratorium Kultur Jaringan Teknologi Benih Fakultas Pertanian Universitas Padjadjaran pada bulan Maret 2012 sampai dengan bulan Juni 2012.

Metode penelitian yang digunakan adalah metode eksperimental berupa Rancangan Acak Lengkap (RAL) pola faktorial yang terdiri dari 15 perlakuan. Dalam setiap perlakuan dilakukan tiga kali ulangan dan setiap ulangan terdiri dari dua unit percobaan yang berisi masing-masing satu buah eksplan. Media dasar yang digunakan adalah media dasar MS. Jumlah keseluruhan bahan percobaan yang dipergunakan adalah 90 unit percobaan. Urutan perlakuan sebagai berikut : Faktor I adalah jenis eksplan (a) terdiri dari 3 taraf, yaitu : $a_{1}$ : mata tunas, $a_{2}$ : pucuk, dan $a_{3}$ : potongan daun, sedangkan faktor II adalah jenis dan konsentrasi sitokinin (s), terdiri dari 5 taraf, yaitu : $\mathrm{s} 0$ (kontrol); $\mathrm{s}_{1}\left(0.5 \mathrm{mgL}^{-1}\right.$ BAP); s2 (1.0 mg L-1 BAP); s3 (0.5 mg L-1 zeatin); $\mathrm{S}_{4}\left(1 \mathrm{mg} \mathrm{L}^{-1}\right)$. Biakan disimpan pada temperatur 22-25 ${ }^{\circ} \mathrm{C}$ pada intensitas cahaya 1000 lux selama 16 jam setiap hari.

\section{Hasil dan Pembahasan}

Jumlah Tunas. Penggunaan eksplan mata tunas, tunas pucuk dan daun pada $12 \mathrm{mst}$, terlihat bahwa pemberian $0,5 \mathrm{mgL}^{-1}$ BAP menghasilkan jumlah tunas yang lebih banyak dibandingkan dengan perlakuan sitokinin lainnya, namun pada eksplan daun pemberian $0,5 \mathrm{mgL}^{-1} \mathrm{BAP}$ tidak berbeda nyata dengan pemberian $1 \mathrm{mgL}^{-1}$ zeatin. Pemberian 0,5 $\mathrm{mgL}^{-1}$ BAP dengan menggunakan eksplan mata tunas menghasilkan jumlah tunas yang lebih banyak walaupun tidak berbeda nyata dengan menggunakan eksplan tunas pucuk, sementara pada pemberian $1 \mathrm{mgL}^{-1}$ zeatin dengan menggunakan eksplan daun justru menghasilkan jumlah tunas yang lebih banyak.

Tabel 1. Rata-rata Jumlah Tunas pada Eksplan dengan Jenis dan Konsentrasi Sitokinin yang Berbeda.

\begin{tabular}{cccccc}
\hline \hline Perla- & \multicolumn{5}{c}{ Jumlah Tunas 12 mst (buah) } \\
\cline { 2 - 6 } kuan & \multicolumn{5}{c}{ Jenis dan Konsentrasi Sitokinin (s) } \\
\hline $\begin{array}{c}\text { Jenis } \\
\text { Eksplan } \\
\text { (a) }\end{array}$ & $\mathbf{s}_{\mathbf{0}}$ & $\mathbf{s}_{\mathbf{1}}$ & $\mathbf{s}_{\mathbf{2}}$ & $\mathbf{s}_{\mathbf{3}}$ & $\mathbf{s}_{\mathbf{4}}$ \\
\hline $\mathbf{a}_{\mathbf{1}}$ & $8,33 \mathrm{a}$ & $32,83 \mathrm{a}$ & $13,5 \mathrm{a}$ & $9,58 \mathrm{~b}$ & $18,92 \mathrm{~b}$ \\
& $\mathrm{D}$ & $\mathrm{A}$ & $\mathrm{C}$ & $\mathrm{D}$ & $\mathrm{B}$ \\
$\mathbf{a}_{\mathbf{2}}$ & 5,31 a & $30,92 \mathrm{ab}$ & 14,89 a & $11,17 \mathrm{~b}$ & $16,47 \mathrm{~b}$ \\
& $\mathrm{D}$ & $\mathrm{A}$ & $\mathrm{B}$ & $\mathrm{C}$ & $\mathrm{B}$ \\
$\mathbf{a}_{3}$ & $1,72 \mathrm{~b}$ & $28,08 \mathrm{~b}$ & 11,92 a & 19,08 a & $30,11 \mathrm{a}$ \\
& $\mathrm{D}$ & $\mathrm{A}$ & $\mathrm{C}$ & $\mathrm{B}$ & $\mathrm{A}$ \\
\hline \hline
\end{tabular}

Keterangan : Angka yang ditandai huruf kapital yang sama (arah horizontal) dan huruf kecil yang sama (arah vertikal) tidak berbeda nyata menurut Uji Jarak Berganda Duncan pada taraf $5 \%$.

Pertumbuhan tunas asal eksplan pucuk dan daun lebih rendah daripada eksplan mata tunas, diduga tidak adanya dominansi apikal pada eksplan mata tunas sehingga pertumbuhan tunas lateral tidak terhambat, sejalan dengan pernyataan Malek et al. (2007) yang melaporkan bahwa eksplan mata tunas lebih mampu meningkatkan jumlah tunas dibandingkan dengan menggunakan eksplan pucuk.

Pemberian BAP pada konsentrasi $1 \mathrm{mgL}^{-1}$ menghasilkan jumlah tunas yang lebih sedikit dibandingkan dengan penggunaan BAP konsentrasi $0,5 \mathrm{mgL}^{-1}$ (Gambar 1), hal ini menunjukkan bahwa peningkatan konsentrasi BAP dapat menurunkan jumlah tunas. Sejalan dengan penelitian Norrizah et al. (2012) yang melaporkan 
bahwa peningkatan konsentrasi BAP justru tidak meningkatkan jumlah tunas yang terbentuk karena setelah mencapai kadar optimal, peningkatan kadar BAP menghambat pertumbuhan tunas.
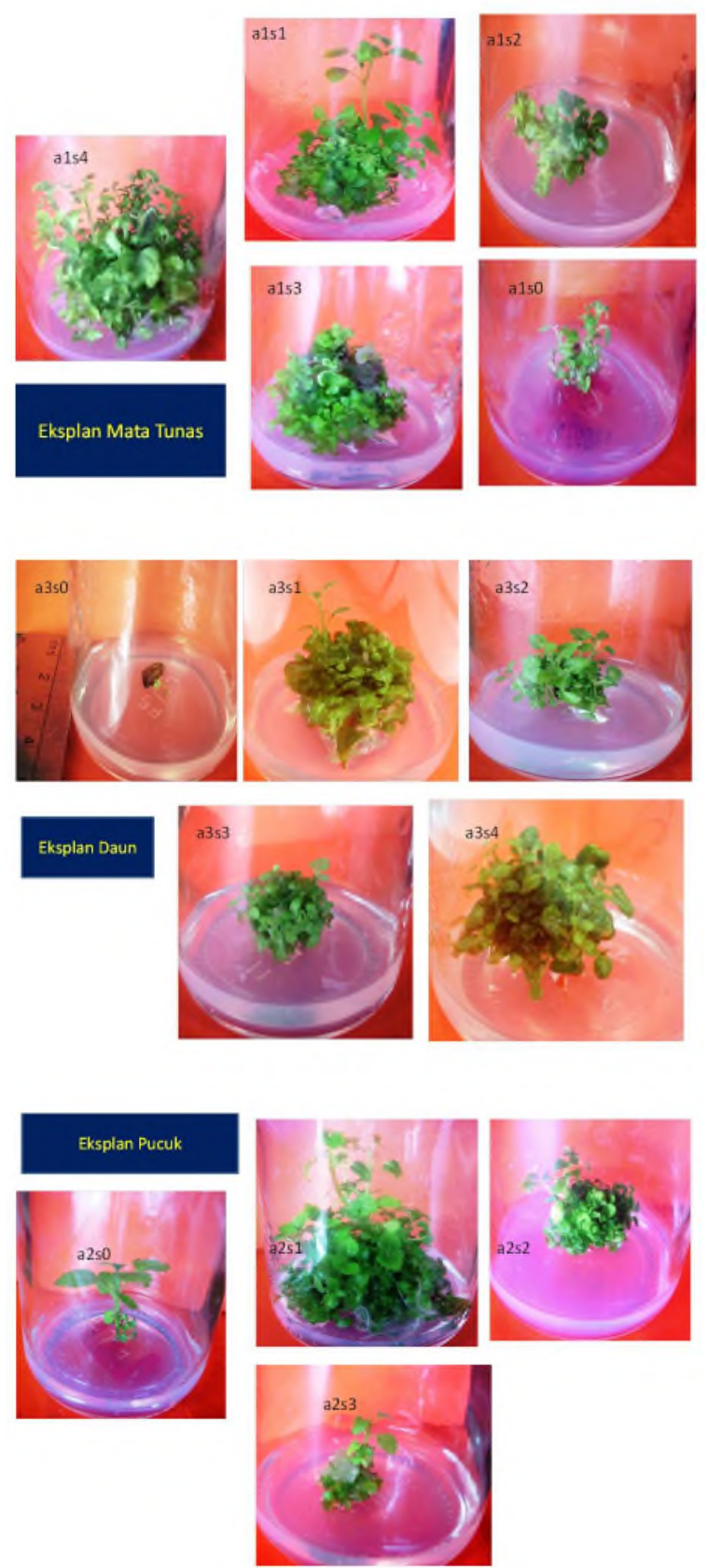

\section{Gambar 1. Pertumbuhan Eksplan Mata Tunas, Pucuk, dan Daun.}

Pemberian jenis sitokinin zeatin masih belum mampu memberikan hasil yang lebih baik dibandingkan dengan pemberian jenis sitokinin BAP. Zeatin pada konsentrasi yang rendah yaitu $0,5 \mathrm{mgL}^{-1}$ menghasilkan jumlah tunas yang sedikit sementara BAP pada konsentrasi $0,5 \mathrm{mgL}^{-1}$ telah mampu menghasilkan jumlah tunas tertinggi jumlahnya. BAP ternyata memiliki efektivitas yang lebih baik daripada zeatin dalam perbanyakan tunas. Wattimena dkk. (1992) menyatakan bahwa BAP pada tanaman secara fisiologis mendorong pembelahan sel, morfogenesis dan pertunasan, selain itu menurut Ghanti et al. (2003) BAP dapat menekan terjadinya dominasi apikal dan memecahkan dormansi tunas lateral.

Penggunaan zeatin terlihat lebih efektif setelah eksplan 12 mst (Tabel 1) yaitu pada konsentrasi $1 \mathrm{mgL}^{-1}$ dengan penggunaan eksplan daun (Gambar 1). Hal ini menunjukkan bahwa pada eksplan daun akan beregenerasi menghasilkan tunas yang lebih banyak jika dikulturkan pada media yang mengandung zeatin dengan konsentrasi yang lebih tinggi yaitu $1 \mathrm{mgL}^{-1}$. Zeatin konsentrasi tinggi dapat menekan efek inhibitor ABA yang ada di daun (Ella dan Zapatta, 1991).

Jumlah Daun. Tabel 2 menunjukkan bahwa pada penggunaan eksplan mata tunas $\left(\mathrm{a}_{1}\right)$ dan tunas pucuk $\left(a_{2}\right)$, pemberian $0,5 \mathrm{mgL}^{-1} \mathrm{BAP}\left(\mathrm{b}_{1}\right)$ menghasilkan jumlah daun yang lebih dibandingkan perlakuan sitokinin lainnya, sementara pada eksplan daun $\left(\mathrm{a}_{3}\right)$ pemberian $1 \mathrm{mgL}^{-1}$ zeatin $\left(b_{4}\right)$ menghasilkan jumlah daun yang lebih banyak namun tidak berbeda nyata dengan pemberian 0,5 $\mathrm{mgL}^{-1}$ BAP. Pemberian $0,5 \mathrm{mgL}^{-1}$ BAP menghasilkan jumlah daun yang labih banyak untuk semua jenis eksplan, sementara pada pemberian $1 \mathrm{mgL}^{-1}$ zeatin dengan menggunakan eksplan daun menghasil-kan jumlah daun yang lebih banyak dibandingkan penggunaan eksplan mata tunas dan tunas pucuk.

Penambahan sitokinin jenis BAP lebih efektif dari pada zeatin dalam mendorong sel-sel meristem pada eksplan untuk membelah dan mempengaruhi sel lainnya untuk berkembang menjadi tunas dan membentuk daun. Hasil penelitian ini sejalan dengan penelitian Ahanhanzo et al. (2010) yang melaporkan bahwa pemberian BAP dibandingkan dengan zeatin lebih efektif dalam merangsang pembentukan morfologi eksplan terutama dalam pembentukan daun. Jenis eksplan juga berpengaruh terhadap peningkatan jumlah daun karena kandungan hormon endogen yang berbeda.

Respon eksplan terhadap pemberian ZPT dipengaruhi oleh genotipe, hormon dan umur eksplan (Chakravarthi et al. 2010).Pemberian 
sitokinin pada eksplan mata tunas dan tunas pucuk menghasilkan jumlah daun yang lebih banyak dibandingkan dengan eksplan daun. Diduga kandungan hormon sitokinin endogen pada eksplan mata tunas dan tunas pucuk lebih tinggi dari pada eksplan daun. Bushra et al. (2009) menyatakan bahwa eksplan mata tunas dan tunas pucuk memiliki kandungan sitokinin endogen yang cukup tinggi, sehingga dengan pemberian sitokinin yang rendah telah mampu beregenerasi dengan baik menghasilkan tunas dan daun.

Tabel 2. Jumlah Daun yang Dihasilkan dari Berbagai Jenis Eksplan dengan Penggunaan Sitokinin yang Berbeda.

\begin{tabular}{|c|c|c|c|c|c|}
\hline \multirow{2}{*}{$\begin{array}{c}\begin{array}{c}\text { Perla- } \\
\text { kuan }\end{array} \\
\text { Jenis } \\
\text { Eksplan } \\
\text { (a) }\end{array}$} & \multicolumn{5}{|c|}{ Jumlah Daun (helai) } \\
\hline & $\mathbf{s}_{\mathrm{o}}$ & $\mathrm{s}_{1}$ & $\mathbf{s}_{2}$ & $\mathrm{~s}_{3}$ & $\mathbf{s}_{4}$ \\
\hline $\mathbf{a}_{1}$ & $\begin{array}{c}41,42 \mathrm{a} \\
\mathrm{C}\end{array}$ & $\begin{array}{c}150,44 \text { a } \\
\text { A }\end{array}$ & $\begin{array}{c}91,44 \\
\mathrm{ab} \\
\mathrm{B}\end{array}$ & $\begin{array}{c}56,25 \mathrm{~b} \\
\mathrm{C}\end{array}$ & $\begin{array}{c}96,58 \mathrm{~b} \\
\mathrm{~B}\end{array}$ \\
\hline $\mathbf{a}_{2}$ & $\begin{array}{c}37,75 a \\
D\end{array}$ & $\begin{array}{c}163,17 \mathrm{a} \\
\mathrm{A}\end{array}$ & $\begin{array}{c}101,67 \\
\text { a } \\
\text { B }\end{array}$ & $\begin{array}{c}69,00 \mathrm{~b} \\
\mathrm{C}\end{array}$ & $\begin{array}{c}91,92 \mathrm{~b} \\
\mathrm{~B}\end{array}$ \\
\hline $\mathbf{a}_{3}$ & $\begin{array}{c}11,67 \mathrm{~b} \\
\mathrm{C}\end{array}$ & $\begin{array}{c}143,83 \text { a } \\
\text { A }\end{array}$ & $\begin{array}{c}77,33 \mathrm{~b} \\
\mathrm{~B}\end{array}$ & $\begin{array}{c}91,00 \text { a } \\
\text { B }\end{array}$ & $\begin{array}{c}163,11 \text { a } \\
\text { A }\end{array}$ \\
\hline
\end{tabular}

Keterangan : Angka yang ditandai huruf kapital yang sama (arah horizontal) dan huruf kecil yang sama (arah vertikal) tidak berbeda nyata menurut Uji Jarak Berganda Duncan pada taraf $5 \%$.

Tinggi Tunas. Eksplan mata tunas $\left(a_{1}\right)$ dan tunas pucuk $\left(\mathrm{a}_{2}\right)$ perlakuan kontrol $\left(\mathrm{b}_{0}\right)$ menghasilkan tunas yang lebih tinggi dibandingkan dengan perlakuan sitokinin lainnya, sedangkan pada eksplan daun $\left(\mathrm{a}_{3}\right)$ pemberian $0,5 \mathrm{mgL}^{-1} \mathrm{BAP}$ $\left(b_{1}\right)$ juga menghasilkan tunas yang lebih tinggi namun tidak berbeda nyata dengan pemberian 1 $\mathrm{mgL}^{-1}$ BAP $\left(\mathrm{b}_{2}\right)$. Perlakuan kontrol dengan menggunakan eksplan mata tunas dan tunas pucuk menghasilkan tunas yang lebih tinggi dibandingkan dengan penggunaan eksplan daun.

Penggunaan eksplan mata tunas dan tunas pucuk dengan perlakuan $\mathrm{s}_{0}$ (tanpa sitokinin) menghasilkan tunas yang lebih tinggi dibandingkan dengan perlakuan sitokinin lainnya, sementara pada eksplan daun pemberian $1 \mathrm{mgL}^{-1}$ zeatin menghasilkan tunas yang lebih tinggi. Perlakuan kontrol dengan menggunakan eksplan mata tunas dan tunas pucuk meng-hasilkan tunas yang lebih tinggi dibandingkan dengan penggunaan eksplan daun, sementara pada pemberian $1 \mathrm{mgL}^{-1}$ zeatin dengan menggunakan eksplan daun menghasilkan tunas yang lebih tinggi dibandingkan dengan penggunaan eksplan mata tunas dan tunas pucuk.

Tabel 3. Rata-rata Tinggi Tunas dengan Jenis Eksplan dan Konsentrasi Sitokinin yang Berbeda.

\begin{tabular}{cccccc}
\hline \hline Perla- & \multicolumn{5}{c}{ Tinggi Tunas 12 mst (cm) } \\
\cline { 2 - 6 } kuan & \multicolumn{5}{c}{ Jenis dan Konsentrasi Sitokinin (b) } \\
\hline $\begin{array}{c}\text { Jenis } \\
\text { Eksplan } \\
\text { (a) }\end{array}$ & $\mathbf{s}_{\mathbf{0}}$ & $\mathbf{s}_{\mathbf{1}}$ & $\mathbf{s}_{\mathbf{2}}$ & $\mathbf{s}_{\mathbf{3}}$ & $\mathbf{s}_{\mathbf{4}}$ \\
\hline $\mathbf{a}_{\mathbf{1}}$ & $2,99 \mathrm{a}$ & $2,28 \mathrm{a}$ & $0,89 \mathrm{a}$ & $0,61 \mathrm{a}$ & $1,77 \mathrm{a}$ \\
& $\mathrm{A}$ & $\mathrm{B}$ & $\mathrm{D}$ & $\mathrm{D}$ & $\mathrm{C}$ \\
$\mathbf{a}_{2}$ & $3,01 \mathrm{a}$ & $2,20 \mathrm{a}$ & $0,99 \mathrm{a}$ & $0,72 \mathrm{a}$ & $1,46 \mathrm{~b}$ \\
& $\mathrm{~A}$ & $\mathrm{~B}$ & $\mathrm{D}$ & $\mathrm{D}$ & $\mathrm{C}$ \\
$\mathbf{a}_{3}$ & $0,29 \mathrm{~b}$ & $1,78 \mathrm{~b}$ & $0,73 \mathrm{a}$ & $0,85 \mathrm{a}$ & $1,86 \mathrm{a}$ \\
& $\mathrm{C}$ & $\mathrm{B}$ & $\mathrm{B}$ & $\mathrm{B}$ & $\mathrm{A}$ \\
\hline \hline
\end{tabular}

Keterangan: Angka yang ditandai huruf kapital yang sama (arah horizontal) dan huruf kecil yang sama (arah vertikal) tidak berbeda nyata menurut Uji Jarak Berganda Duncan pada taraf $5 \%$.

Berdasarkan hasil tersebut menunjukkan bahwa perlakuan kontrol pada eksplan mata tunas dan tunas pucuk yang rata-rata menghasilkan tunas tunggal (jumlah tunas yang sedikit) justru menghasilkan tunas yang lebih tinggi dibandingkan dengan perlakuan jenis sitokinin lainnya yang menghasilkan tunas majemuk. Terjadinya korelasi yang negatif antara jumlah tunas dengan tinggi tunas ini dipengaruhi oleh pembagian nutrisi. Semakin banyak tunas yang dihasilkan dalam satu botol kultur maka akan semakin besar terjadi kompetisi tunas-tunas terhadap unsur hara yang berada dalam media, sehingga nutrisi yang didapatkan oleh tiap-tiap tunas sedikit (Nasser and Khalifah, 2004).

Pemberian BAP dalam konsentrasi 0,5 mgL1 meskipun menghasilkan jumlah tunas yang lebih banyak pada semua jenis eksplan, ternyata mampu menghasilkan tunas yang lebih tinggi dibandingkan dengan pemberian zeatin dalam konsentrasi $0,5 \mathrm{mgL}^{-1}$. Pada zeatin untuk meningkatkan kualitas dan kuantitas tunas akan menjadi lebih baik daripada pemberian BAP membutuhkan konsentrasi yang lebih tinggi lagi. Hal ini kembali membuktikan bahwa zeatin memiliki keefektifan yang lebih rendah dari BAP pada tanaman nilam varietas Lhokseumawe. Hasil penelitian ini tidak sesuai dengan pendapat Wattimena dkk (1992) bahwa zeatin cukup digunakan dalam jumlah sedikit dan memiliki efektivitas yang tinggi dalam rege- 
nerasi tunas dibandingkan dengan jenis sitokinin lainnya. Hasil percobaan menunjukkan bahwa pemberian $1 \mathrm{mgL}^{-1}$ BAP justru menghasilkan tunas yang pendek, hal ini sejalan dengan hasil penelitian Shagufta et al. (2007) yang melaporkan bahwa BAP pada konsentrasi yang rendah dapat meningkatkan tinggi, namun pada konsentrasi yang tinggi BAP justru mengurangi tinggi tunas.

Bobot Segar. Pertumbuhan dicirikan dengan bertambahnya berat yang irreversible, sehingga pengukuran berat segar tanaman dapat mewakili variabel pertumbuhan tanaman yang dikulturkan. Pada 12 mst, penggunaan eksplan mata tunas $\left(a_{1}\right)$ dan tunas pucuk $\left(a_{2}\right)$ pemberian $0,5 \mathrm{mgL}^{-1}$ BAP $\left(b_{1}\right)$ menghasilkan nilai bobot segar yang lebih tinggi dibandingkan perlakuan sitokinin lainnya, sementara pada eksplan daun $\left(\mathrm{a}_{3}\right)$ pemberian $0,5 \mathrm{mgL}^{-1}$ BAP menghasilkan nilai bobot segar yang lebih tinggi namun tidak berbeda nyata dengan pemberian 1 $\mathrm{mgL}^{-1}$ zeatin $\left(\mathrm{b}_{4}\right)$.

Tabel 4. Rata-rata bobot Segar Tunas (g) dengan penggunaan Berbagai Jenis Eksplan dan Sitokinin.

\begin{tabular}{cccccc}
\hline \hline $\begin{array}{c}\text { Perla- } \\
\text { kuan }\end{array}$ & \multicolumn{5}{c}{ Bobot Segar (g) } \\
\cline { 2 - 6 } $\begin{array}{c}\text { Jenis } \\
\text { Eksplan } \\
\text { (a) }\end{array}$ & $\mathbf{s}_{\mathbf{0}}$ & $\mathbf{s}_{\mathbf{1}}$ & $\mathbf{s}_{\mathbf{2}}$ & $\mathbf{s}_{3}$ & $\mathbf{s}_{\mathbf{4}}$ \\
\hline $\mathbf{a}_{\mathbf{1}}$ & $0,35 \mathrm{a}$ & $3,32 \mathrm{a}$ & $0,58 \mathrm{a}$ & $1,42 \mathrm{a}$ & $1,96 \mathrm{~b}$ \\
& $\mathrm{D}$ & $\mathrm{A}$ & $\mathrm{D}$ & $\mathrm{C}$ & $\mathrm{B}$ \\
& & & & & \\
$\mathbf{a}_{2}$ & $0,24 \mathrm{a}$ & $2,48 \mathrm{~b}$ & $0,98 \mathrm{a}$ & $1,40 \mathrm{a}$ & $1,52 \mathrm{c}$ \\
& $\mathrm{D}$ & $\mathrm{A}$ & $\mathrm{C}$ & $\mathrm{B}$ & $\mathrm{B}$ \\
& & & & & \\
$\mathbf{a}_{3}$ & $0,06 \mathrm{a}$ & $2,79 \mathrm{~b}$ & $0,56 \mathrm{a}$ & $1,70 \mathrm{a}$ & $2,60 \mathrm{a}$ \\
& $\mathrm{D}$ & $\mathrm{A}$ & $\mathrm{C}$ & $\mathrm{B}$ & $\mathrm{A}$ \\
\hline \hline
\end{tabular}

Keterangan : Angka yang ditandai huruf kapital yang sama (arah horizontal) dan huruf kecil yang sama (arah vertikal) tidak berbeda nyata menurut Uji Jarak Berganda Duncan pada taraf $5 \%$.

Pemberian 0,5 $\mathrm{mgL}^{-1}$ BAP dengan menggunakan eksplan mata tunas menghasilkan nilai bobot segar yang lebih tinggi dibandingkan penggunaan eksplan tunas pucuk dan daun, sementara pada pemberian $1 \mathrm{mgL}^{-1}$ zeatin dengan menggunakan eksplan daun justru menghasilkan nilai bobot segar yang lebih tinggi dibandingkan penggunaan eksplan mata tunas dan tunas pucuk (Tabel 4.).Eksplan mata tunas dengan pemberian $0,5 \mathrm{mgL}^{-1} \mathrm{BAP}$ menghasilkan bobot segar yang lebih tinggi dibandingkan perlakuan lainnya dan pening- katan bobot segar pada eksplan mata tunas juga sejalan dengan tingginya nilai rata-rata jumlah tunas dan jumlah daun Hal ini berarti bahwa interaksi antara eksplan mata tunas dengan 0,5 $\mathrm{mgL}^{-1}$ BAP sesuai untuk meningkatkan metabolisme sehingga dapat meningkatkan pertumbuhan dan perkembangan (regenerasi) nilam var. Lhokseumawe in vitro.

Penggunaan BAP dengan konsentrasi yang lebih tinggi yaitu $1 \mathrm{mgL}^{-1}$ menyebabkan pertumbuhan eksplan terhambat yang ditandai dengan rendahnya bobot segar nilam. Vescovi et al. (2012) melaporkan bahwa pada konsentrasi sitokinin yang tinggi dapat terjadi apoptosis pada eksplan yang disebabkan jika sel eksplan mengalami aktivitas yang meningkat sehingga pertumbuhan eksplan akan menjadi lambat bahkan terhenti.

\section{Kesimpulan dan Saran}

1. Jenis eksplan, jenis dan konsentrasi sitokinin berpengaruh terhadap pertumbuhan dan perkembangan tunas nilam varietas Lhoukseumawe secara in vitro terlihat pada peubah jumlah tunas, tinggi tunas, jumlah daun, dan bobot segar.

2. Penggunaan eksplan mata tunas dengan pemberian $0,5 \mathrm{mgL}^{-1}$ BAP menghasilkan jumlah tunas, jumlah daun, dan bobot segar yang terbaik.

\section{Ucapan Terima Kasih}

Terima kasih disampaikan kepada Direktur Penelitian dan Pengabdian kepada Masyarakat Direktorat Jenderal Pendidikan Tinggi, Departemen Pendidikan dan Kebudayaan melalui Lembaga Penelitian dan Pengabdian kepada Masyarakat Universitas Padjadjaran yang telah mendanai kegiatan ini melalui Program Penelitian Hibah Bersaing Program Desentralisasi Universitas Padjadjaran Tahun 2012.

\section{Daftar Pustaka}

Ahanhanzo, C., Ch. B. Gandonou, A. Agbidinoukoun, A. Dansi and C. Agbangla. 2010. Effect of two cytokinins in combination with acetic acid a-Naphthalene on yams (Dioscorea spp.) genotypes response to in 
vitro morphogenesis. African Journal of Biotechnology Vol. 9(51), pp. 8837-8843.

Bushra, Z., N. A. Abbasi, T. Ahmad, and I. A. Hafiz. 2009. Effect of explant sources and different concentrations of plant growth regulators on in vitro shoot proliferation and rooting of avocado (Persea americana Mill.) cv. 'Fuerte'. Pak. J. Bot., 41 (5) : 2333-46.

Chakravarthi D.V.N., Indukuri V., Goparaju U.A., Yechuri V. 2010. Effect of genotype, explant and hormonal concentration on in vitro response of eggplant. Not Sci Biol 2(3): 77-85.

Direktorat Jendral Perkebunan. 2007. Nilam. Statistik Perkebunan Indonesia 2003-2006.

Ella, E. S., F. J. Zapatta. 1991. Effect of abscisic acid and zeatin on plant regeneration Using leaf explant of Oryza sativa L. 'Nona Bokra'. Philipp J. Crop Sci 16 (1) : 3-6.

Ghanti, K. S., B. Govindaraju, R. B. Venugopal, S. Ramgopal, C. P. Kaviraj, Jabeen, Arvind., and S. Rao. 2004. High frequency shoot regeneration from Phyllanthus amarus Schum. and Thonn. Indian J. of Biotech. Vol 3: 103 - 107.

Hadipoentyanti, E. 2010. Perbanyakan Benih Nilam Veritas Unggul Sidikalang (Produksi Minyak $\geq 300 \mathrm{~kg} / \mathrm{ha}$ ), Sehat dan Murah Hasil Kultur Jaringan (30 \% dari Biaya Standar). Balai Penelitian Tanaman Obat dan Aromatik. Bogor.

Hua J., Cheng D.Z., Hong H. 2014. Effect of explant types and plant growth regulators on direct regeneration in medicinal plant 'Pogostemon cablin'. Plant Omics. Vol. 7 (5): 322-327.

Malek, M. A., M. A. Barimiah, M. Al-Amin, D. Khanam and M. Khatun. 2007. In vitro regeneration in pointed gourd. Bangladesh J. Agril. Res. 32(3) : 461 - 471.

Nasser, S. and Al-Khalifah. 2004. The Role of Biotechnology in Developing Plant Resources in Desert Environment. International Conference on Water Resources and Arid Environment.

Norrizah, S.M., W.N. Hidayah, S. Aminah, S. Ruzaina, and P. Faezah. 2012. Effect of medium strenght and hormones concentration on regeneration of Pogostemon cablin using nodes eksplan. Asian J. of Biotech. Vol. 4 (1) : 46 - 52.

Rahmat R.A. 2011. Nilam aceh primadona Pasar. http:/ / www.harianaceh.co/read/2011/11 /26/22702/nilam-aceh-primadona-pasar. Diakses tanggal 12 Oktober 2015.

Shagufta, N., A. Ali, F. Ahmad, Siddique, and J. Iqbal. 2007. Multiple shoot formation from different explants of chick pea (Cicer arietinum L). Pak. J. Bot., 39(6): 2067-2073.

Swamy M.K., S. Balasubramanya, M. Anuradha. 2010. In vitro multiplication of Pogostemon cablin Benth. through direct regeneration. African J. Biotech. Vol. 9(14) : 2069-2075.

Vescovi, M., M. Riefler, M. Gessuti, O. Novak, T. Schmulling and F. Lo Schiavo. 2012. Programmed cell death induced by high levels of cytokinin in Arabidopsis cultured cells is mediated by the cytokinin receptor CRE1/AHK4. J. Exp. Bot. 63(7): 2825-32.

Wahyudi A., Ermiati. 2012. Prospek Pengembangan Industri Minyak Nilam di Indonesia. Bunga Rampai Inovasi Tanaman Atsiri Indonesia.Balai Penelitian Tanaman Rempah dan Obat. Bogor. Hal 1-6.

Wattimena, G.A., L.W.Gunawan, N.A. Mattjik, E. Syamsudin, N. M. Armini, dan A. Ernawati 1992. Bioteknologi Tanaman. Tim Laboratorium Kultur Jaringan Tanaman, PAU Bioteknologi IPB. hal 12 - 75.

Yuhono JT., Suhirman S. 2006. Status Pengusahaan Minyak Atsiri dan Faktor-faktor Teknologi Pasca Panen yang Menyebabkan Rendahnya Rendemen Minyak. Bul. Littro Vol. XVII (2) : 79 -90. 